Eos, Vol. 84, No. 32, 12 August 2003

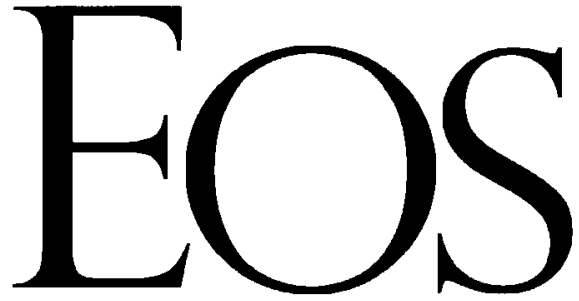

EOS, TRANSACTIONS, AMERICAN GEOPHYSICAL UNION
VOLUME 84 NUMBER 32

12 AUGUST 2003

PAGES 301-312

\title{
Amphibious Seismic Survey Images Plate Interface at 1960 Chile Earthquake
}

\author{
PAGES 301,304-305
}

The southern central Chilean margin at the site of the largest historically recorded earthquake in the Valdivia region, in $1960\left(\mathrm{M}_{\mathrm{w}}=9.5\right)$, is part of the $5000-\mathrm{km}$-long active subduction system whose geodynamic evolution is controversially debated and poorly understood. Covering the area between $36^{\circ}$ and $40^{\circ} \mathrm{S}$, the oceanic crust is segmented by prominent fracture zones. The offshore forearc and its onshore continuation show a complex image with segments of varying geophysical character, and several fault systems active during the past 24 m.y.

In autumn 2001 , the project SPOC was organized to study the Subduction Processes Off Chile, with a focus on the seismogenic coupling zone and the forearc. The acquired seismic data crossing the Chilean subduction system were gathered in a combined offshore-onshore survey, and provide new insights into the lithospheric structure and evolution of active margins with insignificant frontal accretion.

In this article, the first images are presented of the predominantly land-based components of SPOC in southern central Chile, which was a collaborative effort of several German and Chilean institutions. These new seismic data provide constraints on the continuation of fault structures at depth, on deep crustal structures, and on Moho depth. Finally, the plate interface of the 1960 rupture event is evident in the near-vertical incidence reflection section and calibrated with results from the wide-angle velocity model, suggesting the relocation of the 1960 earthquake at $73^{\circ} 05^{\circ} \mathrm{W}$.

\section{Aims and Motivation}

Convergent continental margins are the Earth's principal locus of important earthquake hazards. Some $90 \%$ of global seismicity and all interplate megathrust earthquakes with $\mathrm{M}>8$ occur in the seismogenic coupling zone between the converging plates. However, the processes that shape the coupling zone and

By C. KRAWCZYK AND THE SPOC TEAM its relation to surface deformation are poorly understood. Seismogenic coupling zones occupy a limited depth range between 5-10 $\mathrm{km}$ depth at the updip end, and $30-60 \mathrm{~km}$ at the downdip end (Figure 1, inset). Stronger asperities or material-state variations are supposed to control the strength of the seismogenic coupling zone and subduction channel [Ruff, 1999; Pacheco et al., 1993], while extent and degree of seismic coupling play a major role in great interplate earthquakes [e.g., Oleskevich, 1999].

The long-term vision of our integrated study is a quantitative understanding of mega-thrust earthquake seismicity in subduction zones, and its relation to processes at depth and at the surface. We have started with a series of experiments in the area of the 1960 Chile earthquake that is designed to (1) image the plate interface from the updip to below the downdip end of the seismogenic part, in order to (2) yield key petrophysical and mechanical properties with (3) their variation along different along-strike segments of the plate interface which are at different stages of the seismic rupture cycle, and (4) determine their effect on surface deformation.

\section{Regional Setting}

The southern central Chilean convergent margin provides a first site for our studies (Figure 1). Here, the largest instrumentally recorded earthquake occurred in $1960\left(\mathrm{M}_{\mathrm{w}} 9.5\right)$. The ruptured zone,starting at $38^{\circ} \mathrm{S}$ at a hypocentral depth of some $30-40 \mathrm{~km}$ below the continental forearc, extended progressively toward the south for approximately $1000 \mathrm{~km}$ [Cifuentes, 1989] with a co-seismic slip of up to $40 \mathrm{~m}$, up to $2 \mathrm{~m}$ vertical displacement, and a tsunami up to $15 \mathrm{~m}$ high that affected the entire Pacific [Kanamor and Cipar, 1974; Plafker and Savage, 1970]. Recent GPS data reveal this part of the upper plate to be still in the post-seismic relaxation stage [Klotz et al., 2001].

\section{Experiment Components of SPOC}

The first component of the study, the shipborne geophysical experiment SPOC with the R/V
SONNE, took place in fall and winter 2001/ 2002 , and was operated by the BGR, GEOMAR, and the Berlin-Potsdam Andes research group, SFB 267 (Figure 1). It will yield a near-threedimensional image of the offshore forearc, including the updip parts of the seismogenic coupling zone of the 1960 Chile earthquake segment, and the seismic gap segment to the north [Reichert and SPOC, 2002].

Between $36^{\circ}$ and $39^{\circ} \mathrm{S}$, a predominantly land-based combined onshore-offshore, active-passive seismic experiment was carried out, operated by the GFZ Potsdam and the FU Berlin, linking the marine profiles to the subduction features observed onshore. It comprised (1) a pilot near-vertical incidence reflection (NVR) seismic experiment covering the onshore-offshore transition along a W-E line to test the structural and reflectivity potential along the seismogenic plate interface, and (2) a threedimensional-wide angle reflection/refraction component with the aim of comparing different segments of the Chilean continental margin.

\section{The NVR Seismic Experiment}

The NVR land component at $38^{\circ} 15^{\prime} \mathrm{S}$ covers the near-shore part of the subduction zone between the South American and Nazca plates along the westernmost part of a longer refraction line (Figure 1). The 54-km-long W-E line was set up in three spreads, and recorded a series of 14 shots fired at 10 different locations (Table 1). This resulted in a single-fold CDP coverage along a $71 \mathrm{~km}$-long profile encompassing a 45-km-long portion with two-fold CDP coverage. In addition, the airgun shots of the offshore profile SO161-38/42 were recorded with the first $18 \mathrm{~km}$ of the onshore NVR spread.

\section{The Wide-angle Seismic Experiment}

The wide-angle seismic experiment simultaneously recorded the airgun pulses from $R / V$ SONNE with 30 three-component stations deployed in an array, 52 stations along three consecutive W-E profiles, 22 OBH/OBS stations along the offshore part of the profile at $38^{\circ} 15^{\prime} \mathrm{S}$, and 6 three-component broadband stations along a profile at $39^{\circ} \mathrm{S}$ (Figure 1). Furthermore, eight chemical shots were fired, mainly at the ends of the three W-E profiles (Table 2). Teleseismic, regional, and local events were recorded by the array and broadband stations, contributing to the passive component of the experiment. 


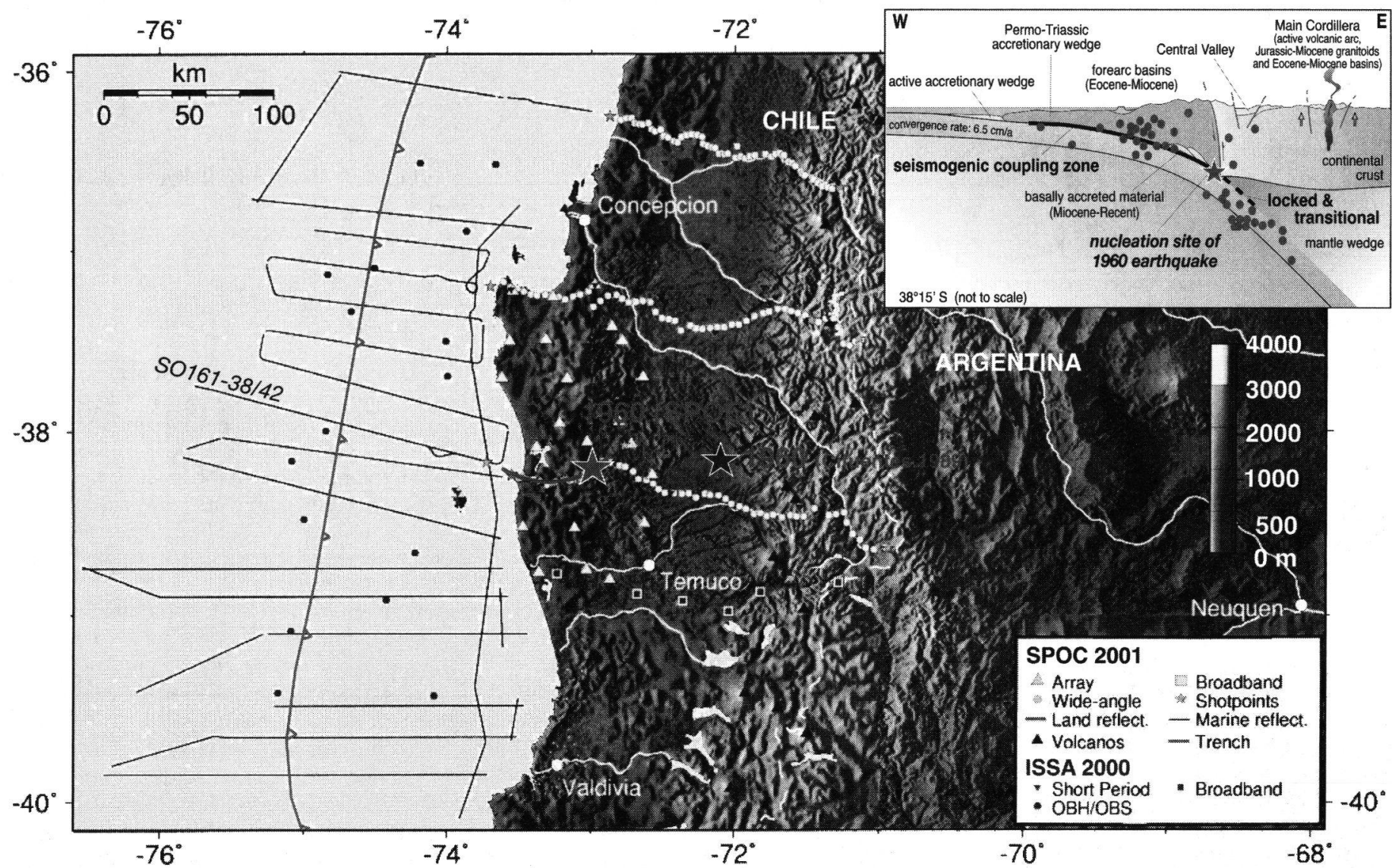

Fig. 1. Map of investigated area with SPOC profile locations. The inset shows a schematic illustration of the conceptual model of crustal structure of the southern Chilean subduction zone at $38^{\circ} 15^{\prime}$ S. The blue asterisk marks the 1960 Valdivia earthquake location from Cifuentes [1989]; the red asterisk marks the suggested relocation. Original color image appears at back of volume.

\section{First Results}

All land data first underwent different processing and modelling procedures (Tables 1 and 2), eventually providing a migrated section and a velocity model along the profile at $38^{\circ} 15^{\prime} \mathrm{S}$ (Figures 2 and 3 ).

The offshore profiles [Reichert and SPOC, 2002] reveal that the upper plate is split into many segments, with pronounced forearc basins and a strikingly narrow accretionary wedge. A thick subduction channel (up to 2 sec TWT) seems to take down the relatively thick trench fill, thereby suggesting a non-frontal accretionary subduction type here.

The onshore NVR section gives an image of different reflection bands in the upper and middle crust (Figure 2). On the entire profile, a subparallel, 3 -km-thick strong reflection band is observed between 8 and $11 \mathrm{~km}$ depth. Different mainly eastward dipping prominent reflection bands are imaged between 5 and 25 $\mathrm{km}$ depth.These bands are interpreted to describe the internal structure of the PermoTriassic accretionary wedge integrating metabasitic and meta-ophiolitic structures in a dominantly meta-sedimentary, basally accreted nappe pile.

Finally, in the western part of the seismic reflection profile, some reflections which weaken eastwards are found between 18 and $30 \mathrm{~km}$ depth (Figure 2). All these eastward dipping reflection bands between 20 and $45 \mathrm{~km}$ depth correlate with Wadati-Benioff seismicity, and
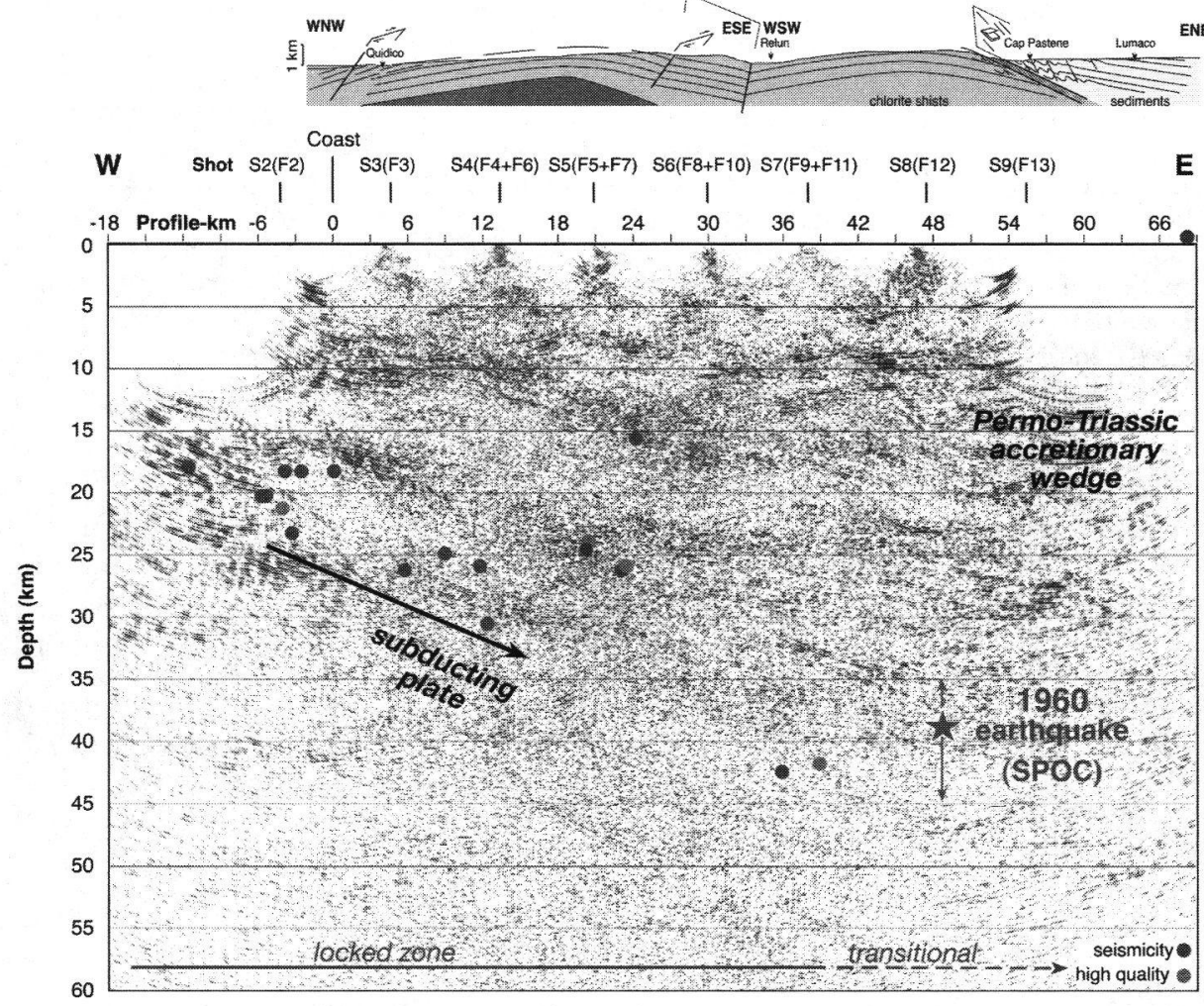

Fig. 2. Depth-migrated reflection seismic profile at $38^{\circ} 15^{\prime} \mathrm{S}$ with seismicity data (green dots from Bohm et al. [2002]). Original color image appears at back of volume. 
can be interpreted as imaging the top of the downgoing plate with a change of the downdip image that approximately correlates with the downdip end of the seismogenic plate interface.

At the latitude of the NVR section, continuous wide-angle data allow the construction of a velocity model from the oceanic crust west of the trench to the continental arc. The oceanic crust is about $7 \mathrm{~km}$ thick (Figure 3).The oceanic Moho is constrained by PmP-reflections down to $45 \mathrm{~km}$ depth under the coastal cordillera.

The continental crust is characterized by gradually increasing average P-wave velocities from west to east. A region of very low P-wave velocities (1.8-5 km/s) may indicate the modern accretionary wedge for about $30 \mathrm{~km}$ east of the trench, and further landwards may be correlated with the dominantly meta-sedimentary basement observed onshore. Under the coastal cordillera and the Longitudinal Valley, a continental Moho was not observed, indicating that here a rather smooth transition, in terms of seismic velocities, occurs from continental to oceanic crust.

The near-vertical and wide-angle reflection data provide the structural framework for the interpretation of observed seismicity and crustal deformation at the Chilean margin between 36 and $39^{\circ} \mathrm{S}$. Recent seismicity [e.g., Bohm et al.,2002] is concentrated in the continental crust and along the oceanic/continental crust boundary beneath the coastline, and in the downgoing slab under the Longitudinal Valley and the main cordillera (Figure 3). The hypocenter of the great 1960 earthquake [Cifuentes, 1989] plots within the lower continental crust under the Longitudinal Valley. However, with respect to the location uncertainty of the earthquake (Figure 3), the E-W error is the largest, while the N-S and depth errors are smaller. Since the new data present for the first time the slab geometry in the region, we suggest the relocation of the 1960 Valdivia earthquake hypocenter further west at, or immediately above, the presumed slabcontinental Moho boundary (Figure 3 ). Thus, the 1960 mega-thrust earthquake would have initiated at $73^{\circ} 05^{\prime} \mathrm{W}$. Future relocation of seismic events and receiver function analyses for continental Moho depth determination for the region will focus on these questions.

\section{Acknowledgments}

We thank all participants in the field for their enthusiasm, and for having made this campaign possible. This survey was funded with research grants from GFZ Potsdam, FU Berlin, DFG (SFB 267), and the German Ministry of Research (BMBF, grant 03G0161A); seismic equipment was provided by the Geophysical Instrument Pool Potsdam and the FU Berlin.

\section{SPOC Research Group (onshore)}

M.Araneda, SEGMI, Santiago, Chile; G. Astroza, Universidad de Concepción (Concepción); K. Bataille, Universidad de Concepción (Concepción); J. Bribach, GeoForschungsZentrum, Potsdam; I. Cartes, Universidad de Concepción (Concepción); E. Carvacho,Universidad

\section{Table 1. Acquisition and Processing Parameters of the SPOC (Subduction Processes Off Chile) Onshore Near-vertical Reflection Component.}

\author{
Acquisition Parameters \\ Recording period \\ Recording systems \\ Sample rate \\ Number of profiles \\ Profile length
9.11. - 5.12.2001
( 6 channels, GPS-clock, 1 GByte hard disk)
$5 \mathrm{~ms}$, continuous recording 1
$71 \mathrm{~km}$ along CDP line, $54 \mathrm{~km}$ along spread \\ 30 Teledyne PDAS-100 seismological recorders
}

\begin{tabular}{ll}
\hline Receiver Specifications & \\
Number of channels & 30 units $\times 6$ channels \\
Geophone type & Sensor SM 6, 4.5 Hz, vertical \\
Receiver array & 6 per group, linear pattern $15 \mathrm{~m}$ in-line \\
Group spacing & $100 \mathrm{~m}$ \\
Block move-up & $18 \mathrm{~km}$ \\
Spread length & $18 \mathrm{~km}$ \\
Number of stations & 540
\end{tabular}

Source Specifications

Explosive Charge

1 Sea: $50 \mathrm{~kg}$ in $190 \mathrm{~m}$ water depth

1 Sea: $25 \mathrm{~kg}$ in $40 \mathrm{~m}$ water depth

11 Land: $75 \mathrm{~kg}$ per shot in $20 \mathrm{~m}$ depth (1 hole)

Configuration

Shotpoint spacing

1 Land: $150 \mathrm{~kg}$ in 2 holes of $20 \mathrm{~m}$ depth

Number of shots

Subsurface coverage

Data amount

4 shots per set-up $(-13.5,-4.5,4.5,13.5 \mathrm{~km})$

$9 \mathrm{~km}+2$ far-offset shots

14 (at 10 different locations)

two-fold ( $50 \mathrm{~m}$ bins)

$14 \times 180$ channels $\times 12000$ samples $=121$ Mbyte

\section{Processing Sequence}

CDP geometry

Amplitude correction

Frequency filtering

Static corrections

Dynamic corrections

Deconvolution

CDP stack

Coherency enhancement

Wave-equation migration crooked-line design (50 m binning) spherical divergence, AGC, trace equalization DC-removal and bandpass

floating datum before/fixed datum after NMO velocity model from SPOC refraction line in $\mathrm{f}-\mathrm{x}$ domain

2-fold

in tau-p domain

FD method to depth
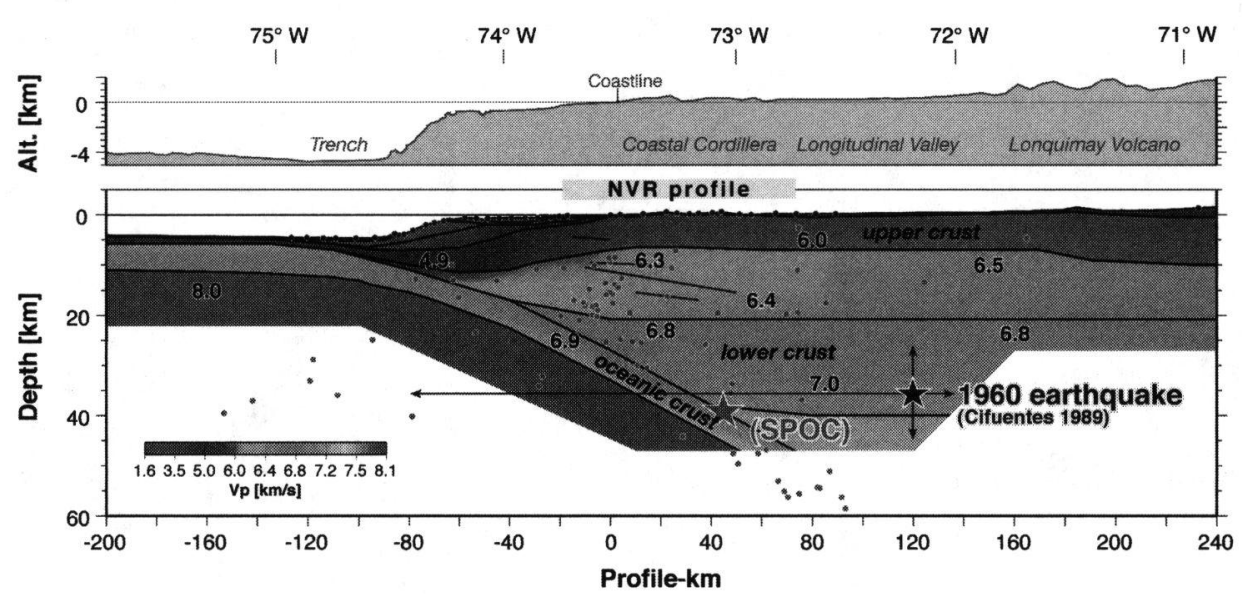

Fig. 3. Velocity model of the two-dimensional, wide-angle seismic profile at $38^{\circ} 15^{\prime} \mathrm{S}$, with local seismicity (red dots from Bohm et al. [2002]). The blue asterisk marks the 1960 Valdivia earthquake location from Cifuentes [1989]; the red asterisk marks the relocation suggested in this article. Arrows indicate range of earthquake locations given by different authors. Original color image appears at back of volume. 
Eos, Vol. 84, No. 32, 12 August 2003

de Concepción (Concepción); A. Cser, Universidad de Concepción (Los Angeles); H. Echtler, GeoForschungsZentrum, Potsdam; E. R. Flüh, GEOMAR, Kiel; J.-A. Gueldner, Free University, Berlin; M. Heigel, Free University, Berlin; C. M. Krawczyk, GeoForschungsZentrum, Potsdam; S. Lüth, Free University, Berlin; S. Martin, Potsdam University; J. Mechie, GeoForschungsZentrum, Potsdam;O.Oncken, GeoForschungsZentrum, Potsdam; B. Orlowsky, Free University, Berlin; L. Rabenstein, Free University, Berlin; C. Reichert, Federal Institute for Geosciences and Natural Resources, Hannover; V. Rocabado, Fundacion Venezolana de Investigaciones Sismologicas; P.Roewer, Free University, Berlin; W.Schnurr, Free University,Berlin;M.Stiller,GeoForschungsZentrum, Potsdam; P. Wigger, Free University, Berlin; M.Yoon, Free University, Berlin; and the SO-161 Shipboard Scientific Party

\section{References}

Bohm, M., S. Lüth, H. Echtler, G. Asch, K. Bataille, C. Bruhn, A. Rietbrock, and P.Wigger,The southern Andes between $36^{\circ}$ and $40^{\circ} \mathrm{S}$ latitude: seismicity and average seismic velocities, Tectonophysics, $356,275-289,2002$.

Cifuentes, l. L., The 1960 Chilean earthquakes,J. Geoph. Res., 94(B1),665-680, 1989

Kanamori,H. and J. J.Cipar, Focal process of the great Chilean earthquake May 22,1960 , Physics Earth and Planetary Interiors, 9, 128-136, 1974.

Klotz, J., G. Khazaradze, D. Angermann, C. Reigber, R. Perdomo, and O.Cifuentes, Earthquake cycle dominates contemporary crustal deformation in Centra and Southern Andes, EPSL, 193(3-4),437-446, 2001

Oleskevich, D. A., R. D. Hyndman, and K. Wang, The updip and downdip limits to great subduction earthquakes: Thermal and structural models of Cascadia, south Alaska, SW Japan, and Chile, J. Geoph. Res., 104(B7), 14,965-14,991, 1999.

Pacheco, J.F, L. R. Sykes, and C. Scholz, Nature of seismic coupling along simple plate boundaries of the subduction type, J. Geoph. Res., 98(B8), 14, 133-14,159, 1993.

Plafker, G., and J.C.Savage, Mechanism of the Chilean earthquakes of May 21 and 22, 1960, Geol. Soc. Am. Bull, 8I(4), 1001-1030, 1970.
Table 2. Acquisition and Processing Parameters of the SPOC (Subduction Processes Off Chile) Onshore Wide-angle Component.

\begin{tabular}{ll}
\hline Acquisition Parameters & \\
Recording period & $27.10 .-1.12 .2001$ \\
Recording systems & 52 Teledyne PDAS-100; 30 RefTek 72A-07; 6 \\
& Guralp CMG-3ESPD/SAM-2 seismological \\
& recorders \\
& (3 channels + GPS-clock, hard disk: PDAS 1 \\
& GByte, Reftek 3 GByte, Guralp 4.5 GByte) \\
& 10 ms, continuous recording \\
Sample rate & $3+$ array \\
Number of profiles & profiles: onshore $150-235 \mathrm{~km}, 145-180 \mathrm{~km}$ \\
Profile length & offshore; array: $100 \times 200 \mathrm{~km}$ \\
&
\end{tabular}

Receiver Specifications

Number of channels

Geophone type

3

MARK L-4C-3D, Guralp CMG-40T, Guralp CMG3ESPD

Station spacing

$2.5-4.5 \mathrm{~km}$ - profiles; $20-40 \mathrm{~km}$ - array

\section{Source Specifications}

Explosive Charge

Shotpoint spacing

Number of shots

Data amount

Sea: $200 \mathrm{~kg}$ in $25 \mathrm{~kg}$ packages

Land: $50-980 \mathrm{~kg}$ in 14 boreholes

$50 \mathrm{~m}$ - airgun pulses, $30-235 \mathrm{~km}$ - chemical shots

8 chemical shots +12600 airgun pulses - profiles; 38250 airgun pulses - array

32 GByte - profiles; 91 GByte - array

Processing/Modelling Sequence

Frequency filtering

Display (plotting)

DC removal and bandpass

Trace-normalized amplitudes

Velocity reduction of 6 or $8 \mathrm{~km} / \mathrm{s}$

Travel-time interpretation

2-D ray-tracing
Reichert, C., and SPOC Scientific Shipboard Party, Subduction processes off Chile: Initial geophysical results of SONNE Cruise SO-161(2+3), Geophysical Research Abstracts, 4, EGS02-A-05338, 2002.

Ruff, L., Dynamic stress drop of recent earthquakes: variations within subduction zones, Pure and Applied Geophysics, 154(3-4), 409-431, 1999.

\section{Author Information}

C. Krawcyzk, GeoForschungsZentrum Potsdam, Germany 
Eos, Vol. 84, No. 32, 12 August 2003

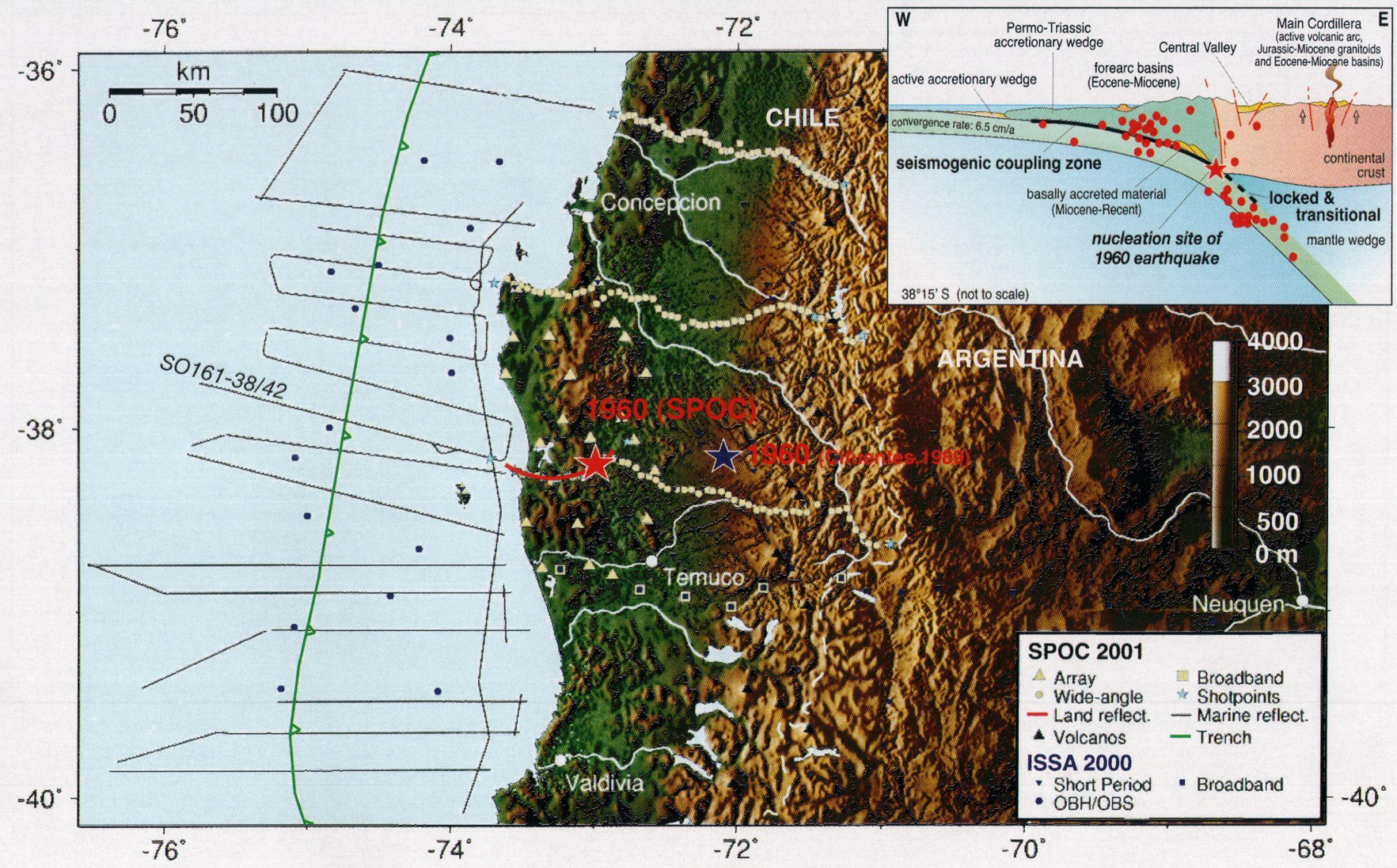

Fig. 1. Map of investigated area with SPOC profile locations. The inset shows a schematic illustration of the conceptual model of crustal structure of the southern Chilean subduction zone at 38¹5'S. The blue asterisk marks the 1960 Valdivia earthquake location from Cifuentes [1989]; the red asterisk marks the suggested relocation.

Page 301 
Eos, Vol. 84, No. 32, 12 August 2003

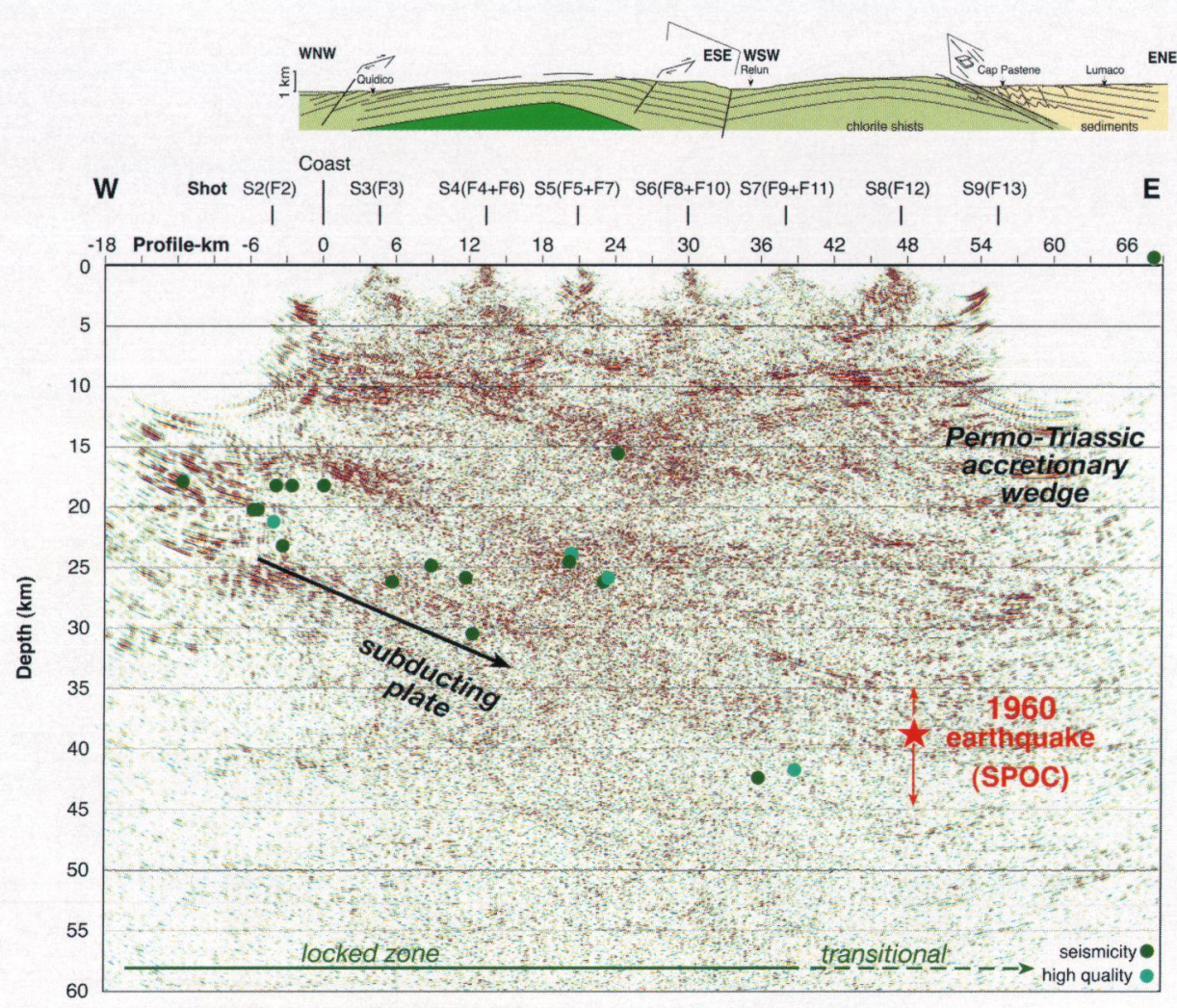

Fig. 2. Depth-migrated reflection seismic profile at $38^{\circ} 15^{\prime} \mathrm{S}$ with seismicity data (green dots from Bohm et al. [2002]).
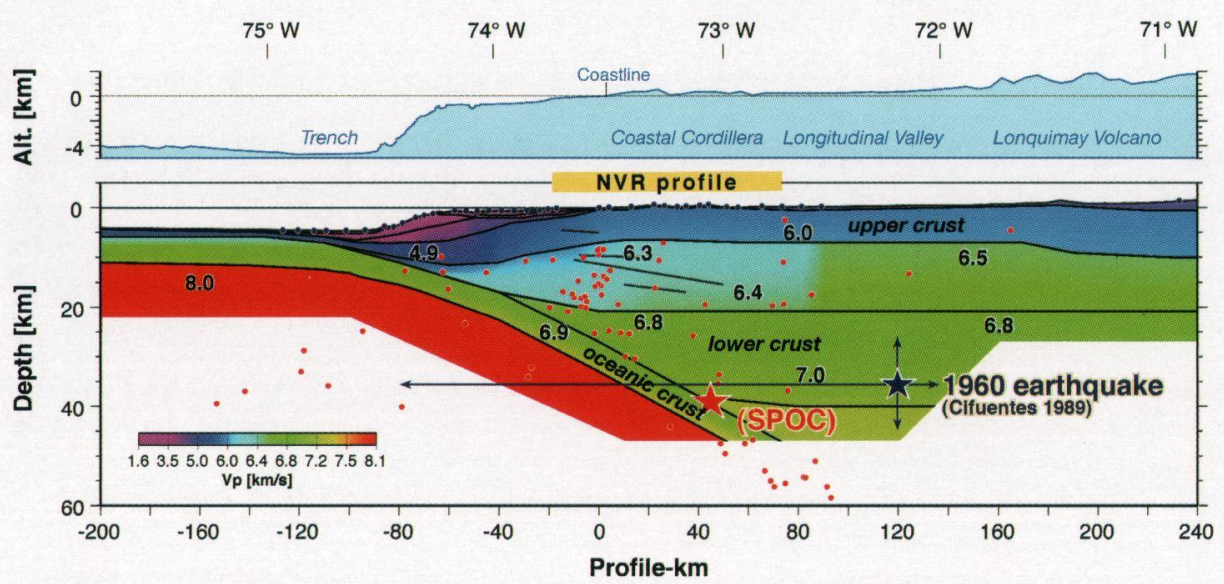

Fig. 3. Velocity model of the two-dimensional, wide-angle seismic profile at $38^{\circ} 15^{\prime} \mathrm{S}$, with local seismicity (red dots from Bohm et al. [2002]). The blue asterisk marks the 1960 Valdivia earthquake location from Cifuentes [1989]; the red asterisk marks the relocation suggested in this article. Arrows indicate range of earthquake locations given by different authors. 